\title{
Tantangan Konektivitas dan Aksesibilitas Dalam Pengembangan Pelayanan Kesehatan Berbasis Telemedicine di Indonesia: Sebuah Tinjauan
}

\author{
Aditya Rachmat Saputro', Amar Ma'aruf Gusnadi², Zahrotul Zanah ${ }^{3}$, Joni Welman \\ Simatupang ${ }^{4}$ \\ 1, 2, 3, 4) Faculty of Engineering, Electrical Engineering Department, President University \\ Jl. Ki Hajar Dewantara \\ Kota Jababeka,Cikarang, Bekasi - Indonesia 17550 \\ Email: aditya.saputro@student.president.ac.id, amar.gusnadi@student.president.ac.id, \\ zahrotul.zanah@student.president.ac.id, joniws@ieee.org
}

\begin{abstract}
ABSTRAK
Kemajuan teknologi telekomunikasi yang pesat telah memengaruhi dunia medis. Saat ini kita mengenal istilah telemedicine yaitu suatu metode dalam dunia medis yang memanfaatkan teknologi telekomunikasi (termasuk internet) di bidang kesehatan untuk mengirim dan menerima berbagai informasi kesehatan dari satu tempat ke tempat lainnya guna meningkatkan pelayanan klinis dalam mendiagnosis dan terapi kesehatan serta pendidikan medis. Telemedicine juga akan sangat berguna pada saat pandemi COVID19 saat ini, karena dapat membantu masyarakat untuk tetap mendapatkan layanan dan informasi kesehatan saat berada di rumah. Meskipun telemedicine sudah masuk dan berkembang di Indonesia dengan cukup signifikan seiring berkembangnya jaringan telekomunikasi dan alat untuk mengaksesnya, akan tetapi penerapan telemedicine di Indonesia mendapatkan tantangan berupa kondisi konektivitas jaringan telekomunikasi dan ketersediaan perangkat untuk mengakses telemedicine yang belum merata di seluruh wilayah Indonesia. Untuk itu, perlu dibuat solusi cepat agar seluruh wilayah di Indonesia dapat mulai menggunakan teknologi telemedicine selain mempercepat pemerataan ketersediaan infrastruktur telekomunikasi dan perangkat untuk mengakses telemedicine.
\end{abstract}

Kata kunci: Indonesia, Telemedicine, Konektivitas, Aksesibilitas, Telekomunikasi. COVID19

\begin{abstract}
The rapid advances in telecommunications technology have influenced the medical world. Today we know the term telemedicine, a method in the medical world that utilizes telecommunications technology (including the internet) in the field of health to send and receive various medical information from one place to another in order to improve clinical services in diagnosing and treating medical therapy and medical education. Telemedicine will also be very useful during the current COVID 19 Pandemic, because it can help people to continue to get health services and information while at home. Telemedicine has entered and developed in Indonesia quite significantly along with the development of telecommunications networks and the means to access it, however the application of telemedicine in Indonesia faces challenges in the form of conditions of telecommunications network connectivity and the availability of devices to access telemedicine which are not evenly distributed throughout Indonesia. For that purpose, it is necessary to make a quick solution so that all regions in Indonesia can start using Telemedicine technology in addition to accelerating equitable distribution of the availability of telecommunications infrastructure and devices to access telemedicine.
\end{abstract}

Keywords: Indonesia, Telemedicine, Connectivity, Accessibility, Telecommunication, COVID19

\section{Pendahuluan}

Teknologi telekomunikasi adalah teknologi untuk saling bertukar informasi dari jarak jauh dengan menggunakan suatu alat bantu. Teknologi telekomunikasi memungkinkan penggunanya untuk dapat bertukar informasi secara cepat, efisien, akurat dan aman. Salah satu pemanfaatan dan pengembangan teknologi telekomunikasi dalam bidang kesehatan adalah teknologi telemedicine. Teknologi telemedicine adalah kegiatan multidisiplin ilmu yang akan menjadi sebuah terobosan dan tantangan besar yang akan memengaruhi penyediaan layanan kesehatan pada abad ini. 
Teknologi telemedicine dapat membantu pasien, pekerja kesehatan dan lembaga kesehatan untuk saling berbagi informasi dengan mudah, cepat dan aman. Saat ini teknologi telemedicine yang berbasis pada jaringan telekomunikasi telah berkembang dan menjadi bagian dari dunia kesehatan. Penggunaan teknologi telemedicine pada dunia kesehatan menjadikan kegiatan-kegiatan seperti pelaporan dan dokumentasi, registrasi, pembayaran, sistem pelayanan kesehatan langsung seperti monitoring pasien dan pemberian obat, menjadi lebih mudah, cepat dan akurat. Saat ini, penggunaan teknologi telemedicine tidak terbatas hanya untuk pasien yang di rawat di instansi kesehatan saja, tetapi juga untuk pasien yang di rawat di luar instansi kesehatan seperti rawat jalan di rumah, kondisi tersebut membuat pengembangan teknologi telemedicine di Indonesia memiliki tantangan baru yaitu konektivitas dan aksesibilitas.

Tantangan konektivitas seperti ketersediaan jaringan telekomunikasi merupakan tantangan terbesar dalam pengembangan teknologi telemedicine, karena jaringan telekomunikasi merupakan alat pendukung utama. Selain itu, ada tantangan aksesibilitas yaitu kemudahan dalam menggunakan teknologi telemedicine. Aksesibilitas juga memengaruhi perkembangan teknologi telemedicine di Indonesia. Oleh sebab itu, perlu dukungan dan inovasi dari semua pihak untuk dapat terus mengembangkan teknologi telemedicine di Indonesia.

Rumusan masalah dari penelitian ini adalah mengenai bagaimana ketersediaan fasilitas dan konektivitas jaringan telekomunikasi untuk mendukung akses teknologi telemedicine di Indonesia, bagaimana pola atau metode yang tepat untuk menerapkan dan mengembangkan teknologi telemedicine di Indonesia, dan apa saja manfaat penerapan teknologi telemedicine pada masa pandemi virus COVID-19 di Indonesia.

Tujuan dari penelitian ini adalah untuk mengetahui bagaimana ketersediaan fasilitas dan konektivitas jaringan telekomunikasi di untuk mendukung akses teknologi telemedicine di Indonesia, mengetahui manfaat penerapan teknologi telemedicine di masa pandemi virus COVID-19, dan mengetahui pola atau metode yang tepat untuk menerapkan dan mengembangkan teknologi telemedicine di Indonesia.

\section{Metode}

Metode penulisan jurnal ini adalah Systematic Literature Review (SLR). Data yang disajikan bersumber dari berbagai jurnal dan artikel online yang ada kaitannya dengan teknologi telekomunikasi dan telemedicine. SLR adalah metode literature review yang mengidentifikasi, menilai, dan menginterpretasikan seluruh temuan pada suatu topik penelitian, untuk menjawab pertanyaan penelitian (research question) yang telah ditetapkan sebelumnya. Metode SLR dilakukan secara sistematis dengan mengikuti tahapan dan protokol yang memungkinkan proses literature review terhindar dari bias dan pemahaman yang bersifat subyektif dari penelitinya. Metode ini berisi ulasan, rangkuman, dan pemikiran penulis tentang beberapa sumber pustaka (artikel, buku, slide, informasi dari internet) tentang topik yang dibahas. Literature review yang baik harus bersifat relevan, mutakhir, dan memadai (Wahono, 2016)

Analisa data adalah proses penyusunan data agar dapat ditafsirkan. Menyusun data berarti menggolongkannya ke dalam pola, tema atau kategori tertentu agar menjadi teratur dan dapat ditafsirkan (Wahono, 2016)

Langkah-langkah analisa data yang dilakukan adalah sebagai berikut:

1. Pengumpulan informasi melalui studi literatur.

2. Reduksi, yaitu memilah informasi mana yang sesuai dan tidak sesuai dengan rumusan masalah.

3. Penyajian, yaitu menyampaikan data-data hasil studi literatur yang telah di pilah-pilah.

4. Penarikan kesimpulan.

\section{Hasil Dan Pembahasan}

\subsection{Pemahaman Tentang Teknologi Telemedicine di Indonesia}

Penggunaan teknologi telemedicine di Indonesia sejak tahun '90an. Saat ini, penggunaan teknologi telemedicine di Indonesia telah mengalami perkembangan yang signifikan, akan tetapi teknologi telemedicine belum digunakan oleh seluruh rakyat Indonesia dikarenakan belum banyak masyarakat yang memahami teknologi telemedicine tersebut. Kondisi ini diperlihatkan oleh data survey dari Asosiasi Penyelenggara Jasa Internet Indonesia tahun 2018 pada Gambar 1. 


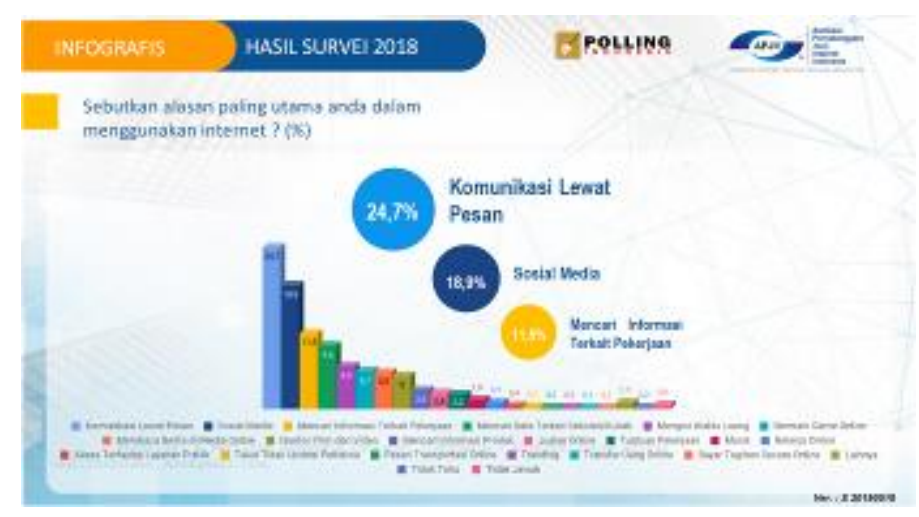

Sumber gambar: Asosiasi Penyedia Jasa Internet Indonesia (APJII). (2019). "Penetrasi \& Perilaku Pengguna Internet Indonesia 2018”. Survey APJII Versi: S 20190518.

Gambar 1. Data survey pemanfaatan internet tahun 2018.

Data survey tahun 2018 tersebut menunjukkan bahwa perilaku mayoritas pengguna internet di Indonesia dalam memanfaatkan internet di tahun 2018 adalah untuk berkomunikasi lewat pesan dan mengakses sosial media, sedangkan pemanfaatan untuk mengakses pelayanan kesehatan masuk dalam kategori "lainnya" yaitu sebanyak $0.9 \%$. Meskipun begitu, ada beberapa upaya yang dilakukan oleh pemerintah dan akademisi untuk terus mengembangkan dan memperkenalkan teknologi telemedicine ke masyarakat. Beberapa contoh teknologi telemedicine yang diperkenalkan adalah sistem telemedicine puskesmas yang dipelopori oleh program studi teknik biomedis Institut Teknologi Bandung (ITB) sejak tahun 1997 dan terus dikembangkan sampai saat ini. Selain itu ada mobile telemedicine yang berupa mobil puskesmas keliling yang dilengkapi dengan perangkat untuk mengakses telemedicine yang digunakan untuk menjangkau wilayah-wilayah pelosok di Indonesia.

\subsection{Kondisi Konektivitas Jaringan Telekomunikasi di Indonesia}

Salah satu jenis jaringan telekomunikasi yang ada di Indonesia adalah jaringan internet. Berdasarkan survei yang dilakukan oleh Asosiasi Penyelenggara Jasa Internet Indonesia (APJII) pada tahun 2018, pengguna jaringan internet di Indonesia sudah mencapai $64,8 \%$ (171,17 juta dari total 264,16 juta populasi penduduk di Indonesia) seperti yang tertera pada Gambar 2.

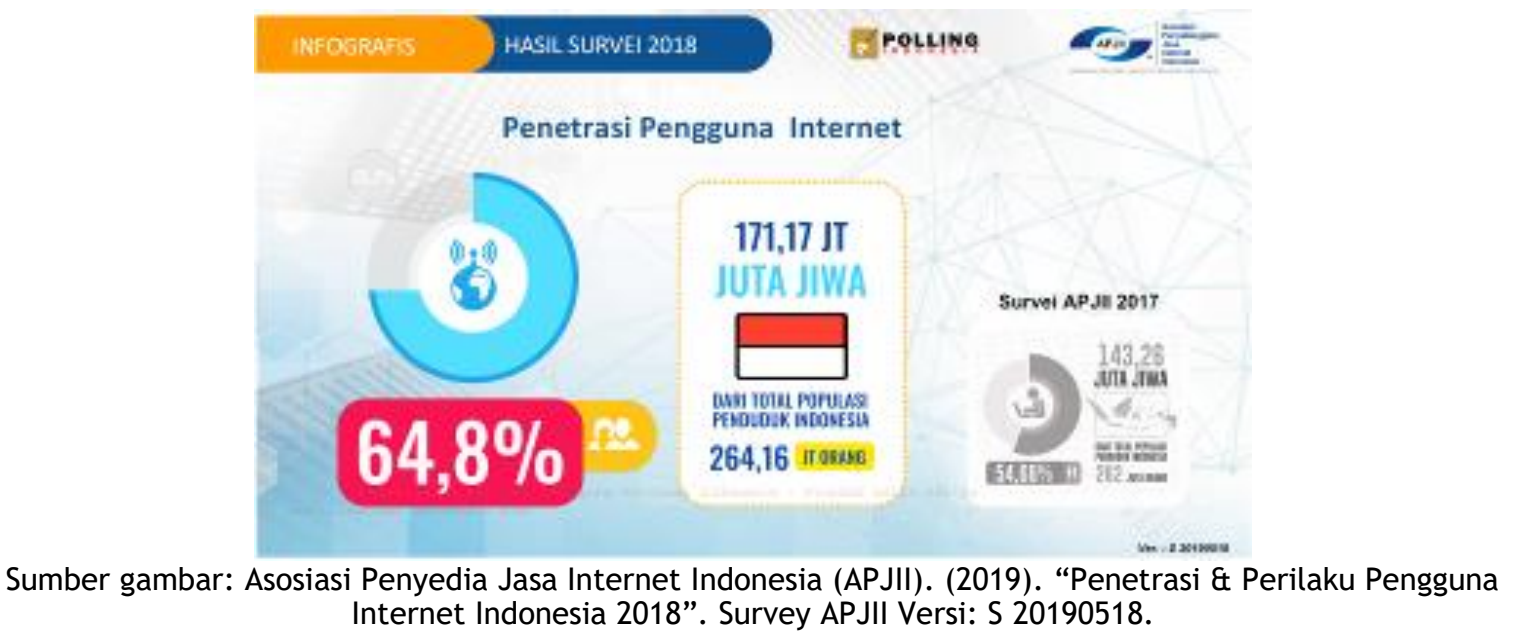

Gambar 2. Data penetrasi pengguna internet di Indonesia tahun 2018.

Pemerintah terus berupaya memperluas jaringan internet salah satunya dengan menambah instalasi kabel fiber optik, bahkan Jaringan optik ini sudah di targetkan oleh pemerintah akan menghubungkan sekitar 514 wilayah di kabupaten dan kota yang ada di indonesia per tanggal 1 Januari 2019. Menteri komunikasi dan informasi bapak Rudiantara menjelaskan bahwa pemerintah akan berkoordinasi dan bekerja sama dengan para penyedia jasa telekomunikasi, terutama Telkom untuk membangun 
infrastruktur broadband ini. Proyek pembangunan infrastruktur fiber optik palapa ring yaitu sepanjang 36.000 kilometer yang terbentang dari wilayah pulau Sumatera, Jawa, Kalimantan, Nusa Tenggara, Papua, Sulawesi, dan Maluku sudah dilakukan. Jaringan tersebut berkapasitas 10 GB dan diharapkan jaringan fiber optik ini dapat menjadi tumpuan untuk jaringan telekomunikasi dan terintegrasi dengan jaringan yang telah ada.

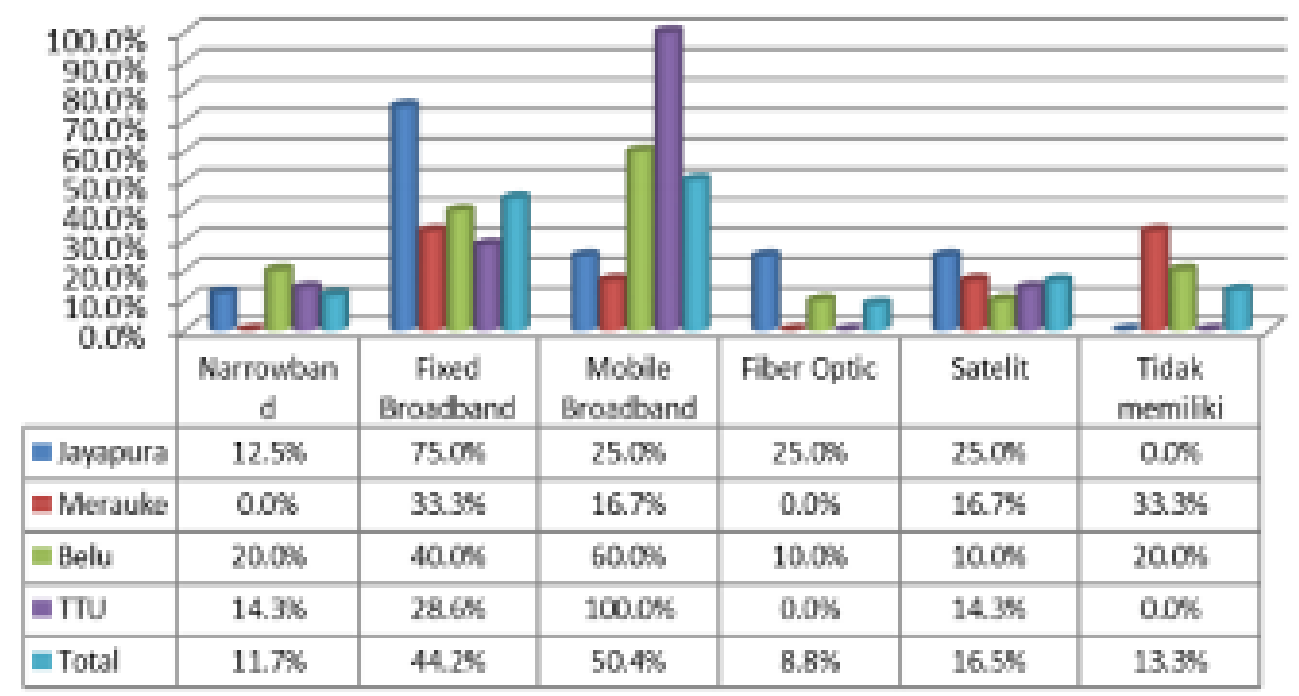

Sumber gambar: Amin, M, 2016, hal. 42

Gambar 3. Grafik penggunaan jaringan telekomunikasi di daerah Indonesia bagian timur.

Gambar 3 menunjukkan bahwa jaringan telekomunikasi telah mulai digunakan di wilayah Indonesia bagian timur. Selain data dari grafik diatas, mentri informasi dan komunikasi Republik Indonesia bapak Rudiantara mengatakan bahwa di quartal ketiga 2018 ada sebanyak 2.451 daerah yang tertinggal, serta 306 daerah terluar dan terjauh di wilayah prioritas perbatasan sudah dapat menikmati akses internet. Kinerja ini baru tercapai sekitar 69\% dari target pemerintah, yaitu 4000 daerah hingga 2019 yang dapat menikmati akses internet di daerah yang tertinggal, terluar, dan terjauh [2]. Hal ini menunjukan bahwa sarana penunjang bagi masyarakat untuk mengakses telemedicine sudah sangat berkembang, dengan terjangkaunya akses jaringan internet dan telekomunikasi membuat telemedicine semakin mudah di akses di manapun walaupun di daerah yang tertinggal, terluar, dan terjauh.

\subsection{Ketersediaan Alat Penunjang Untuk Mengakses Teknologi Telemedicine di Indonesia}

Alat untuk mengakses teknologi telemedicine dapat berupa telepon kabel, mesin fax, personal komputer, telepon seluler (smartphone) dan alat medis yang dapat terintegrasi langsung dengan jaringan telekomunikasi. Telepon seluler dan personal komputer bukanlah alat yang asing didengar di hampir seluruh wilayah di Indonesia, persebaran alat-alat tersebut juga sudah hampir menjangkau seluruh wilayah Indonesia.

Perkembangan pengguna telepon seluler dari tahun ke tahun semakin meningkat. Dari Gambar 4 di bawah ini, terlihat data statistik tahun 2014 - 2018 yang menunjukkan persentase kepemilikan telepon seluler setiap tahun mengalami peningkatan. Pada tahun 2018 persentase pengguna telepon seluler di Indonesia adalah 62,41\%. 


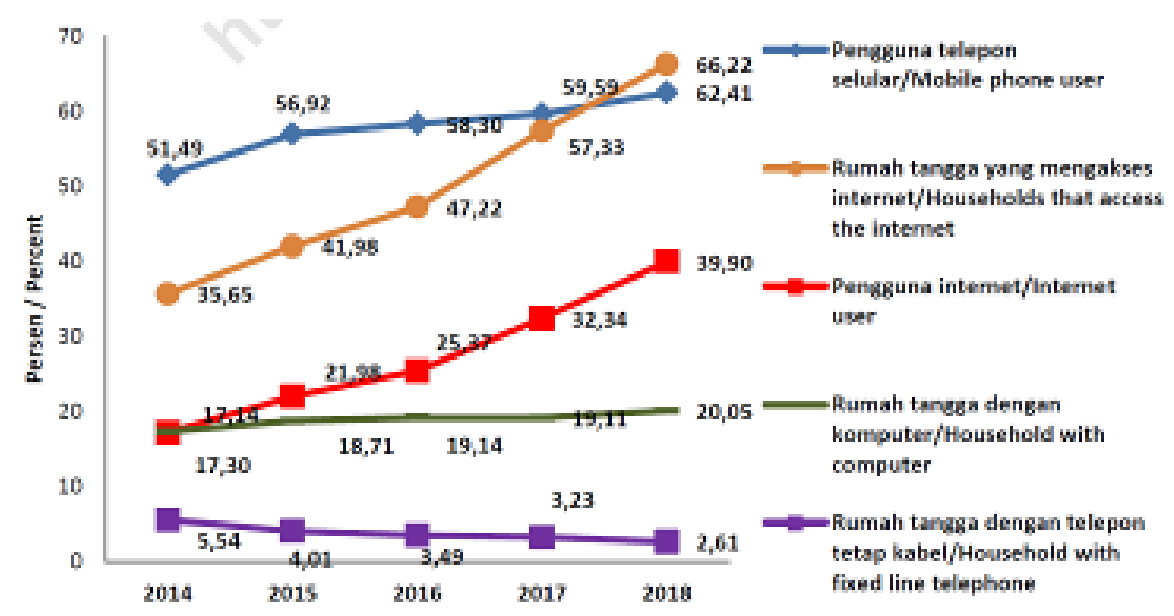

Sumber gambar: Lestari,T.K., 2018.

Gambar 4. Statistik pertumbuhan pengguna telepon seluler antara tahun 2014 - 2018.

Pada Gambar 4 diperlihatkan bahwa persentase "rumah tangga yang mengakses internet", "pengguna internet", dan "rumah tangga dengan komputer" mengalami peningkatan setiap tahun. Trend peningkatan tersebut adalah kabar yang bagus karena dapat membantu perkembangan teknologi telemedicine.

Telemedicine sebenarnya telah dikembangkan di Indonesia sebagai pilot project sejak tahun 2012 dengan jenis layanan teleradiologi saja. Pada tahun 2016, telemedicine dikembangkan menjadi tiga jenis layanan, yaitu teleradiologi, tele-EKG dan tele-USG. Selain itu, saat ini sedang dilakukan pengujian lebih lanjut untuk mengembangkan satu lagi jenis telemedicine yaitu telekonsultasi. Dalam rangka menunjang layanan telemedicine sebagai pilot project, kementerian kesehatan melengkapi sarana meliputi peralatan rontgent digital, alat computed radiography (CR) serta alat scanner radiography. Hingga saat ini pelaksanaan pelayanan telemedicine telah berlangsung di beberapa daerah di Indonesia, Khususnya daerah yang tertinggal, terluar, dan terjauh. Namun pada pelaksanaannya masih banyak ditemui kendala maupun kekurangan.

Dirjen Yankes menjelaskan bahwa suatu program yang dijalankan pastinya mengalami berbagai kendala, terlebih di awal. Terkait telemedicine ini kendala yang sering ditemui adalah berupa permasalahan jaringan, penerima yang tidak aktif menjawab, yang pengirim tidak aktif mengirimkan data, maupun kendala lainnya (Astui, 2018).

\subsection{Penerapan Teknologi Telemedicine Pada Masa Pandemi Virus COVID-19}

Pada masa pandemi COVID-19 peran telemedicine sangat dibutuhkan karena sejak diterapkan protokol pencegahan penularan virus COVID-19 yang salah satunya adalah imbauan untuk melakukan physical distancing, semua kegiatan apapun yang melibatkan beberapa orang sangat dibatasi terutama di bidang kesehatan. Telemedicine merupakan pendekatan inovatif yang dapat memberikan pelayanan kesehatan dari jarak jauh secara online dan dapat digunakan sebagai sarana pemberi informasi kesehatan yang bertujuan agar masyarakat lebih siap secara dini dalam pencegahan dan penanganan menghadapi pandemi COVID-19. Selain itu pemerintah telah menyiapkan beberapa pelayanan dan informasi yang dapat di akses secara online sehingga dapat dimanfaatkan masyarakat luas, seperti panduan cuci tangan yang benar, etika batuk maupun pemakaian masker di tempat umum dan juga menyediakan konsultasi untuk pasien yang mempunyai gejala atau merasakan badan yang kurang sehat dan ingin konsultasi ke dokter melalui online. Tujuannya adalah agar meminimalisir kunjungan ke fasilitas kesehatan sehingga physical distancing dan isolasi mandiri dapat berjalan lebih efektif dan juga diharapkan dapat memutus rantai penularan COVID-19.

Karena kunjungan langsung ke fasilitas kesehatan dapat berisiko tertular virus COVID-19, pemerintah menggandeng beberapa layanan medis online tepercaya sebagai pelayanan kesehatannya dan juga untuk mencegah berita hoax yang kemungkinan dapat tersebar ke masyarakat. "Berdasarkan laporan Menteri Kesehatan (dalam Rapat Kabinet Terbatas Senin 6/4), ada 15 juta orang mengakses 
telemedicine sehingga membantu berkurangnya jumlah pasien yang datang ke Rumah Sakit." Terang Kepala Gugus Tugas Percepatan Penanganan COVID-19, Doni Monardo (Ashar, 2020).

Harapan dari penerapan teknologi telemedicine saat adanya pandemi COVID-19 adalah mengurangi jumlah masyarakat yang mengunjungi rumah sakit, memberikan informasi sebanyak mungkin mengenai COVID-19 sehingga dapat membantu masyarakat untuk mendeteksi dini terhadap kemungkinan terinfeksi virus COVID-19 dan memberikan layanan telekonsultasi sehingga jika memang ada indikasi pengguna aplikasi terjangkit COVID-19 maka akan diberikan panduan penanganan dan panduan untuk mendatangi fasilitas kesehatan (Ashar, 2020)

Pemerintah juga telah menggandeng beberapa aplikasi atau website untuk mendukung jalannya telemedicine diantaranya adalah doktersehat, dokterpedia, halodoc, dan layanan-layanan lainnya. Tujuannya adalah untuk mendukung jalannya telemedicine dan juga memberukan pendampingan kepada pengguna untuk melakukan isolasi secara mandiri (Ashar, 2020). Gambar 5 adalah aplikasi Halodoc yang merupakan salah satu contoh penerapan dari telemedicine yang sedang populer.

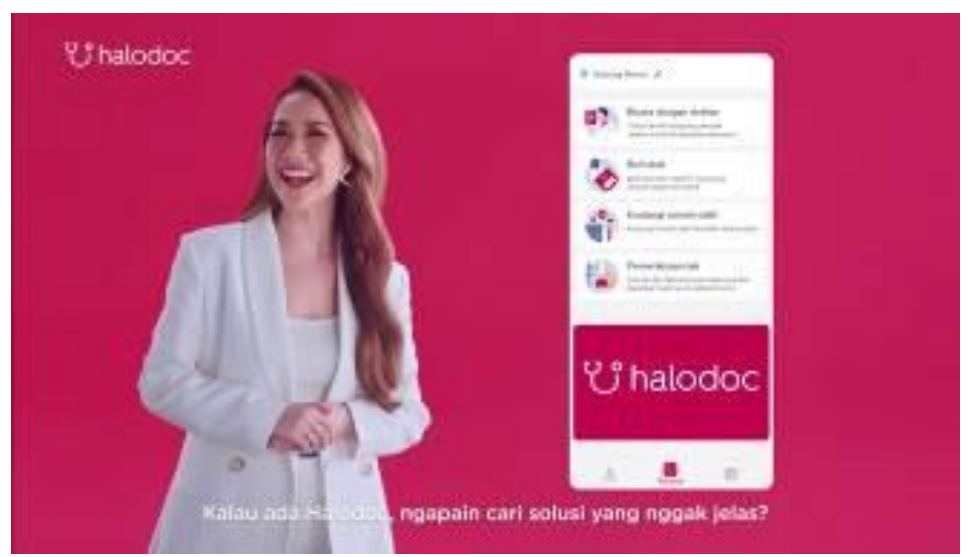

Sumber gambar: https://kesehatan.kontan.co.id/news/marak-konsultasi-virus-corona-startup-telemedicinediakses-15-juta-pengguna. [Diakses: 20-Jul-2020].

Gambar 5. Aplikasi halodoc yang merupakan salah satu penerapan dari teknologi telemedicine.

\subsection{Pola Atau Metode Untuk Menerapkan Teknologi Telemedicine di Indonesia}

Gambar 6 menunjukkan kondisi jaringan telekomunikasi di Indonesia belum merata, kondisi ini diakibatkan oleh bentuk geografis wilayah Indonesia yang terdiri dari hutan, gunung, dan lautan yang menjadi tantangan untuk melakukan pemasangan infrastruktur jaringan telekomunikasi. Akan tetapi, berdasarkan data pengguna jaringan internet yang ditampilkan pada Gambar 2 serta data kepemilikan komputer dan smartphone di Indonesia yang ditampilkan pada Gambar 4, potensi untuk pemerataan pelayanan telemedicine di Indonesia terbuka lebar di kemudian hari. Perlu usaha bersama antara pemerintah dan seluruh rakyat Indonesia untuk membuat telemedicine menjadi lebih berkembang di Indonesia.

Penerapan telemedicine belum merata di seluruh wilayah Indonesia. Beberapa daerah perkotaan di Indonesia sudah dapat menerapkan telemedicine untuk melakukan interaksi antara dokter dengan pasien secara langsung melalui beberapa aplikasi yang tersedia di komputer maupun smartphone. Kondisi ini mungkin dilakukan karena ketersediaan jaringan telekomunikasi dan perangkat untuk mengakses telemedicine. Selain itu, hampir seluruh rumah sakit di kota-kota yang ada di Indonesia sudah memiliki jaringan dan alat untuk mengakses telemedicine. 


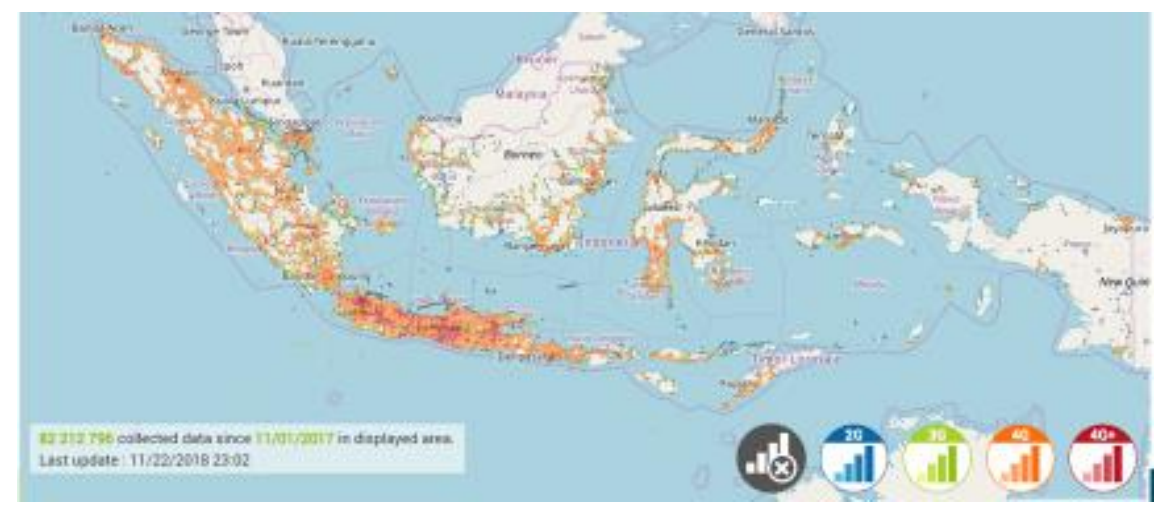

Sumber Gambar: F, Anis. (2018). . https://docplayer.info/116433135-Inovasi-dan-pemanfaatan-teknologidigital-bidang-kesehatan-anis-fuad-departemen-biostatistik-epidemiologi-and-kesehatan-populasifakultas.html [Diakses: 16-Juli-2020].

Gambar 6. Peta persebaran jaringan telekomunikasi di Indonesia.

Sedangkan daerah-daerah pelosok di Indonesia perlu menggunakan metode mobile telemedicine dimana, perlu disediakan perangkat untuk mengakses telemedicine secara portable yang dapat di bawa oleh tenaga medis untuk menghampiri masyarakat yang tinggal di wilayah pelosok, dikarenakan jaringan telekomunikasi yang belum dapat diperoleh secara mudah dan belum tersedianya perangkat untuk mengakses telemedicine secara mudah. Contoh prototype perangkat mobile telemedicine ditunjukkan pada Gambar 7.

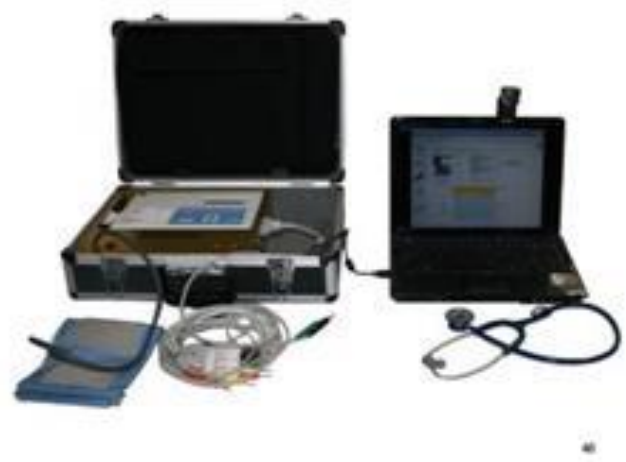

Sumber Gambar: Soegijoko, S. (2010) dalam Santoso, B.S, Rahmah, M., Setiasari, T, dan Sularsih, P., (2015) hal, 6

Gambar 7. Prototype perangkat mobile telemedicine.

Meskipun saat ini perlu menggunakan dua metode yang berbeda untuk menerapkan teknologi telemedicine di Indonesia, berdasarkan data yang ada kuat kemungkinan dalam beberapa tahun mendatang telemedicine dapat digunakan secara merata di seluruh wilayah di Indonesia. Selain itu, segala bentuk edukasi maupun pemberian informasi mengenai telemedicine juga harus di berikan secara merata ke seluruh rakyat Indonesia, dengan tujuan membangun pemahaman tentang pelayanan kesehatan sehingga telemedicine dapat diterima dan digunakan oleh masyarakat.

\section{Kesimpulan Dan Saran}

Teknologi telemedicine secara teori sangat bermanfaat untuk pemerataan pelayanan kesehatan di seluruh wilayah di Indonesia. Namun dibutuhkan infrastruktur yang bagus untuk memeratakan pelayanan kesehatan dengan konsep telemedicine. Dua aspek utama yang perlu diperhatikan: pertama adalah konektivitas jaringan telekomunikasi yang baik dan merata, kedua adalah ketersediaan perangkat untuk mengakses telemedicine yang merata di seluruh Indonesia. Jika salah satu/kedua aspek tersebut belum terpenuhi akan menghambat perkembangan telemedicine.

Saat ini, pemerataan layanan telemedicine di Indonesia masih dalam proses. Ketersediaan jaringan telekomunikasi dan perangkat untuk mengakses berbeda antara daerah perkotaan dengan daerah 
pelosok sehingga daerah perkotaan akan lebih mudah menggunakan telemedicine. Untuk itu, perlu disediakan suatu alat mobile telemedicine yang dapat digunakan oleh tenaga medis sehingga masyarakat di daerah pelosok dapat menikmati layanan kesehatan yang lebih baik atau serupa dengan masyarakat di daerah perkotaan.

Selain jaringan telekomunikasi dan perangkat untuk mengakses, perlu dilakukan edukasi dan pemberian informasi secara massive kepada seluruh masyarakat tentang teknologi telemedicine, sehingga telemedicine dapat diterima dan digunakan dengan baik di masyarakat. Berdasarkan data yang diperoleh, kondisi konektivitas jaringan telekomunikasi di Indonesia terus mengalami peningkatan sehingga semakin banyak daerah yang telah tersedia jaringan telekomunikasi selain itu, data kepemilikan perangkat untuk mengakses telemedicine juga semakin baik, setiap tahunnya terjadi peningkatan jumlah kepemilikan perangkat tersebut, kondisi ini merupakan hal yang baik untuk perkembangan telemedicine di Indonesia.

\section{Daftar Pustaka}

1. Amin, M. (2016), Akses Dan Penggunaan Internet Pita Lebar Di Wilayah Perbatasan (Indonesia - Papua Nugini Dan Indonesia - Timor Leste). Jurnal IPTEK-KOM, 18 (1), 35-50, ISSN 2527-4902.

2. Ashar, S. (2020). "Marak Konsultasi virus corona, startup telemedicine diakses 15 juta pengguna". [online]. Diakses dari https://kesehatan.kontan.co.id/news/marak-konsultasivirus-corona-startup-telemedicine-diakses-15-juta-pengguna pada 20-Jul-2020.

3. Asosiasi Penyedia Jasa Internet Indonesia (APJII). (2019). "Penetrasi \& Perilaku Pengguna Internet Indonesia 2018". Survey APJII Versi: S 20190518.

4. Astuti, D.D. (2018). “Akses internet jangkau 2.451 lokasi di daerah tertinggal”. Diakses dari https: / / www.antaranews.com/berita/761192/akses-internet-jangkau-2451-lokasi-di-daerahtertinggal, pada 15-Juli-2020.

5. Fuad, A. (2018), Inovasi dan Pemanfaatan Teknologi Digital Bidang Kesehatan. Universitas Gadjah Mada, Yogyakarta. Diakses dari https://docplayer.info/116433135-Inovasi-danpemanfaatan-teknologi-digital-bidang-kesehatan-anis-fuad-departemen-biostatistikepidemiologi-and-kesehatan-populasi-fakultas.html pada 16-Juli-2020.

6. Lestrai, T.K., (2018). Statistik telekomunikasi Indonesia 2018. Badan Pusat Statistik, Katalog BPS: 8305002, ISSN : 2476-9134.

7. Santoso, B.S, Rahmah, M., Setiasari, T, dan Sularsih, P., (2015), Perkembangan Dan Masa Depan Telemedika di Indonesia. Procceeding on Conference: National Conference on Information Technology and Technical Engineering (CITEE), https://www.researchgate.net/publication/281497363_PERKEMBANGAN_DAN_MASA_DEPAN_ TELEMEDIKA_DI_INDONESIA

8. Wahono, R.S. (2016). Systematic Literature Review: Pengantar, Tahapan Dan Studi Kasus. [online] tersedia. Diakses dari https://romisatriawahono.net/2016/05/15/systematicliterature-review-pengantar-tahapan-dan-studi kasus pada 15 July 2020 